\title{
Rain rituals and hybridity in Southern Africa
}

\author{
R Müller ${ }^{1}$ \\ (University of Pretoria)
}

\section{ABSTRACT \\ Rain rituals and hybridity in Southern Africa}

This article discusses the persistence and transformation of rain rituals in contemporary African Christianity. It argues that the concept 'hybridity' might be a useful addition to the vocabulary of scholars studying contemporary global Christianity. The use of hybridity could replace ideologically loaded terms, such as syncretism, while still describing the interaction between different religious traditions on the phenomenological level. In Africa, as elsewhere, there are ongoing internal dialogues between the often divergent traditions represented in the worldviews of contemporary Christians. Under the concept hybridity, this internal inter-religious dialogue might be well described using non-pejorative, empirical language.

\section{INTRODUCTION}

It is the thesis of this article that the term "hybridity", which has been well used in post-colonial theory to describe so-called hybrid cultures, may be equally usefully applied in theological studies to describe some of the more recent trends in World Christianity, particularly the phenomenon of African Initiated Christianity. Perhaps it has the potential to circumvent and override some of the more biased connotations associated with typically used concepts, such as syncretism. Although it is possible to use syncretism in a neutral, phenomenological sense, the word has often been negatively applied to certain forms of African Christianity by observers who themselves hold essentialist understandings of religion in general, and Christianity in particular. In such a view, syncretism then denotes a tainted Christianity, namely a non-pure and therefore false form of religion. The term hybridity, on the other hand, seems to evoke an unapologetic sense of blending, whereby two different traditions contribute in roughly equal measure to a new cultural/religious product.

1 Research Associate, Department of Practical Theology, University of Pretoria. 
This may seem like a strange line to take for a theologically trained individual, such as myself. Scholars who work and study in the secular academy may indeed ask, “Aren't you theologians the ones most concerned with protecting the so-called 'purity' of Christianity?" To this question one could respond in a number of ways, which might usefully be the subject of another article. For my purposes here I would simply point out that in recent times there has been a growing consensus among missiological scholars of Global Christianities to recognise the fact, to quote Richard Fox Young, "that all Christians - of Hellenistic antiquity, of medieval Northern Europe, and of today's global South - necessarily construct their pluriform identities out of heterogeneous cultural components" (Young 2006:1). This realization occurred to a large extent under the influence of more recent scholarship done on African Christianity, and particularly by Andrew Walls and what we could call the 'Wallsian' school of African Christian historiography (Walls 1996/2002).

The development of an informed body of theological scholarship on the hybrid nature of intercultural interaction is not restricted to historical and missiological studies on African Christianity. Writing from a Pastoral Theological perspective, Tapiwa Mucherera, for example, accepts hybridity as a given in his discussion of the different levels of consciousness present among Zimbabwe's urban Shona (Mucherera 2001:9-16).

However, despite the growing influence of more culturally aware forms of Christian scholarship on the phenomenology of World Christianities, a redemption and resurrection of the historically unfortunate word syncretism seems highly unlikely. Yet the phenomenon of heterogeneous and culturally dynamic Christianities still begs description. Therefore, we find ourselves in search of new vocabulary.

\section{A PILGRIMAGE IN SEARCH OF RAIN}

Allow me now to refer to field data collected for my $\mathrm{PhD}$ dissertation, when in November, 2005 I accompanied members of South Africa's Zion Christian Church on a cross-border pilgrimage to Botswana. The pilgrimage consisted of tens of thousands of Zionists following their Bishop, Barnabas Lekganyane, who was going to pay a visit to Botswana's capital city, Gaborone, on the invitation of that city's mayor, himself a ZCC member. The 
invitation was accompanied by the request that the Bishop would come and pray for rain, as the country was suffering from a severe drought at the time. The Bishop's visit inspired high hopes among many residents of Botswana, a large number who were members of the ZCC. Their hopes were further bolstered by their memories of Bishop Lekganyane's previous visit to their country in 1999, when good sustaining rains had indeed fallen subsequent to, and as it was believed by many, in consequence of his visit. It should be pointed out that rain has always been the most valuable of commodities in this water-scarce land. This is well symbolised by the fact that Botswana's national currency is the Pula, which means rain in Setswana.

In various ways my companions on the pilgrimage, as well as their Botswana compatriots who met up with us during the weekendlong event, expressed their belief in their Bishop as, "the man who has the key to the rain”. A particular insightful conversation occurred over dinner at a Nando's fast-food restaurant in downtown Gaborone. The three main characters involved in this exchange I will call, James, Jerome, and Solomon. All three were members of the ZCC. Jerome and James were Botswana citizens living in Gaborone. Both were university graduates. Solomon was one of my companions on the pilgrimage. He was a high school teacher from Soshanguve in Gauteng province, South Africa.

The conversation began with James informing the rest of us that second to South Africa, Botswana has the highest number of ZCC members. In proportion to the size of the population, Botswana actually has a much stronger ZCC presence. "The parliament is full of ZCCs", we were told. "Also the police and the defense force". The two university graduates were just as adamant as everyone else that the Bishop's visit was going to bring rain. According to the two, the newspapers had been full of debate about whether this visit would have similar results as the aftermath of Barnabas Lekganyane's visit in 1999. For examples of this debate surrounding the pilgrimage see, for instance, Dikarabo Ramadubu, "ZCC Pilgrims descend on Gaborone”, (Botswana Guardian 18-24 Nov. 2005) and William Kemotho Senthebeng, and Dr. Aaron Majuta, "Exploding Myths about ZCC", (Botswana Guardian 2-8 Dec. 2005). There were some high expectations. "Gaborone will be a little Moria”, one paper had said. Lekganyane had been referred to as the "rain man" and the "man who has the key to rain". 
At one point in the discussion, it was said that the ZCC and Lekganyane should be understood from the cultural point of view of Modjadji, the Rainqueen of the Lovedu. This connection finds support from Van Wyk's data. He mentions the belief among the ZCC that Lekganyane even exceeds Modjadji's rain bringing powers (Van Wyk 1986:417). Nchabeleng relates an interesting anecdote told to him by an informant, intended to illustrate Edward Lekganyane's rainmaking powers: "He once performed a miracle at Jane Furse near Groblersdal. He took a waterpot or calabash and poured water into it and turned it upside down and left it in that position. He told the chief not to touch it until Lekganyane crossed the Olifants river. Before he could cross the river it rained very heavily and the bishop could not cross it and as a result he had to sleep at Apel. It happened because the chief's wife overturned the calabash before the time" (Nchabeleng 1983:101). The Lekganyanes' reputation entrenches their position within the cultural tapestry of an African world that, once suppressed by the white world's evangelists [see Robert Moffat's opinion on rainmakers in Comaroff and Comaroff (1992:242)] now appears to be resurgent. Geoffrey Parrinder gives a wider perspective: "The Lovedu queen is renowned as the greatest rain-maker in South Africa (though the Zulu Chaka declared that he was the greatest of all rain-makers). But there are multitudes of other rain-makers, in all parts of the continent. They are usually men, famous for their powerful medicines” (Parrinder 1976:80).

Jerome further told me that the Botswana ZCCs, although numerous, tend to be not as devout in their following of Lekganyane as the people of the Polokwane area, "where he is regarded as a god". I, at first thought this was a positive comment on the theological sensibilities of the Batswana, until he continued to explain that he himself had spent two weeks at Moria on one occasion, at the end of which he had left, "convinced that Lekganyane is Jesus"2. James now elaborated on this theme by

2 Cf Hanekom (1975), where he relates an explanation by one of his informants that Moria is better than other places, because the Bishop resides there. There they feel themselves closer to Modimo. The man tells among other things of how he had become cured of an illness after staying for three weeks at Moria, and with Edward Lekganyane praying for him, morning and evening (Hanekom 1975:86). These sorts of testimonies would seem to indicate that while both Moria and the Bishop are powerful entities of healing in their own 
saying one newspaper had suggested that people had waited long enough for Jesus of Nazareth to come to them. There was now a man from South Africa, who was indeed going to make his appearance.

James said that many of his friends found it strange that he would remain in the ZCC with his level of education. They thought he should become a Roman Catholic. "What do I want to be Catholic for? The ZCC is African, and it is traditional". "They think the ZCC is for poor people”, Solomon explained to me, referring to the critics. Jerome summed up the situation under confirmation by the others: "I want to be a fulltime African, not only part-time". In a similar vein he found the belief in the God of Abraham, Isaac, and Jacob nonsensical. The ZCC believes in the God of Engenas, Edward, and Barnabas. He found it surprising that some other Christian groups, most notably the Assemblies of God, regarded the ZCC as lost, in need of salvation.

\section{PRAYERS ANSWERED AND PROPHECIES FUL- FILLED}

The following night, Saturday, the night preceding the scheduled event when the Bishop was going to address the pilgrims at a local soccer stadium, some hard driving rain fell virtually right through until dawn.

The next morning the place was flooded. When I stepped out of the car where I had been sleeping, my foot landed in a rather deep puddle of water that had formed next to the car. People were in a happy mood, although no one was surprised at the extent of the rains. This was exactly what they had expected, not because anyone might have had access to a weather forecast, but simply because that was the whole point of the Bishop's visit.

This event led to some particularly strong confessions of faith by some of my companions. At one point, Solomon put me on the spot by quite publicly asking: "Having seen what you have seen, what would you reply if people say to you that Lekganyane is a god?"” And to be honest, in the spirit of the moment, I struggled to

right, the combination of the two, i e the Bishop at work in Moria provides for an extremely potent formula.

3 Van Wyk (1986:407) also mentions the Bishop's rain bringing powers as some of the evidence mentioned by respondents for his divine status, for example: "I am not ashamed to say that Lekganyane is a god, because he gives 
come up with an answer that would convey an "appropriate" degree of academic skepticism. In truth, I could hardly avoid conceding that some of the empirical evidence seemed to support the contention regarding the Bishop's special powers. After all, had I not seen rains falling after severe droughts, both here and at Kimberley during a previous pilgrimage in the wake of Bishop Lekganyane? I think the point here is that I could quite easily see how they could believe so firmly in their Bishop's special powers. Perhaps it is no wonder that what the Kriges observed in the 1940's among the Lovedu appears to be equally true for the $21^{\text {st }}$ century ZCC: "Neither European contact nor Christianity has succeeded in breaking down the implicit belief of every member of the tribe in the power of the queen to make rain" (Krige \& Krige 1943:281). The only differences, of course, are that the words "tribe" and "queen" should respectively be substituted for ZCC and Bishop.

What is significant, however, about Solomon's question regarding the Bishop's divinity is that he had on a number of previous occasions during our time together openly denounced those people who "think that he [Lekganyane] is a god". He had also on earlier occasions denied that the Bishop might have any "special powers" over the rain. "No", Solomon had assured me, he is merely "praying for rain". Beliefs, however, are not static constructs, particularly not in the ZCC context, where as I have found, textbased doctrinal formulations play virtually no part. And so Solomon, presented with new evidence during our journeys to both Kimberley and Botswana, comes to the point where he apparently finds it hard to hold his earlier line that the Bishop is neither a god nor a rainmaker. The combined effects of rainfall under unexpected and seemingly providential circumstances, and many hours of ZCC preaching, prophecy, and conversation with his compatriots might have changed his mind. At any rate, we know that seeing is believing (and believing is seeing) and therefore, when Solomon presents me with this question, he might well have been asking himself the same thing: "Having seen what you have seen, what would you reply if people say to you that Lekganyane is a god?” Others were much less circumspect regarding their beliefs in the Bishop's divine status (see

rain" [my translation]. In a similar vein, he says there are known cases where people have driven donkey carts for over $160 \mathrm{~km}$ in order to secure rain from Lekganyane (Van Wyk 1986:408). 
for instance Jerome's statement above). Yet, Solomon's wavering certainty and seemingly internal see-sawing regarding the issue is perhaps more symbolic of the ZCC's position in contemporary South Africa. For not only does the ZCC provide a home for those with fragmented religious identities, in itself it actually straddles different fragmented worlds, and might even be said to present itself as a new vision of an African world, based on a hybridised religious culture.

\section{STATUS OF THE BISHOP}

Interestingly, Bishop Lekganyane never seems to make such claims about himself, although he openly voices his belief in the "power of prayer". Regardless of what the Bishop believes about himself, however, it is to a large extent the beliefs of the ordinary members that sustain the religious culture of the ZCC. A strong case is to be made that the belief in the rainmaking powers of the Bishop is a transposition of older, pre-Christian ideas regarding the rainmaking powers of traditional rulers. Traditional societies in Southern Africa did not, generally speaking, separate the secular and the sacred in the public sphere. A traditional ruler's powers included legal, political, as well as religious roles. With regard to the latter, the ruler was considered to be a mediator between the people and their most important ancestors, namely their previous rulers, who would themselves be the personal ancestors of the living ruler.

Particularly insightful in this regard are two seminal anthropological studies dating back to the first half of the twentieth century. The first is Isaac Schapera's Rainmaking Rites of Tswana Tribes (Schapera 1971). Although the publication date is 1971, Schapera did his actual fieldwork in the late nineteen twenties and early thirties. The second study is the Kriges' The Realm of a RainQueen, which was published in 1943. What is significant about these studies is not only the fact that they deal with the question of African rainmaking among traditional societies, but specifically that they respectively address the two distinct, yet related cultural backgrounds of the main characters involved in the 2005 pilgrimage of Bishop Lekganyane and his followers to Gaborone, Botswana. Schapera's study is situated in what was then the Bechuanaland Protectorate, which is today's Botswana, whereas the Kriges focused on the Lovedu, a Northern Sotho group geographically located in South Africa's Limpopo Province, not far from Moria, the headquarters of the ZCC and place of residence of Bishop Lekganyane. The majority of South Africa's ZCC members are 
comprised of people from the Northern Sotho cultural/linguistic group, including the Bishop himself. Both these studies show that rainmaking and sacral leadership tended to converge in the figure of the traditional ruler.

Therefore, it should perhaps not surprise us that the question of the Bishop's divinity and his status as a rainmaker appear to be inseparably intertwined ${ }^{4}$. If he is in fact fulfilling a similar role to that of a traditional ruler, that should be exactly the case. An outside observer might, for instance, wonder why it is necessary for him to travel to specific areas in order to pray for rain. Could he not simply hold a special prayer service at his residence in Moria for all of Southern Africa? That would, however, largely contravene the conventions of a traditional rainmaking ceremony. For not only is the efficacy of the rainmaking ceremony dependent on the person who does the praying, but the land itself and physical location of the ritual seem just as important. Although the ZCC's headquarters at Moria in the northern Limpopo province has much sacral quality for church members, the ZCC is no localised church, and in fact members live spread out over a large area of Southern Africa. Therefore, prayers for rain done by Barnabas Lekganyane at Moria might be considered effective for the surrounding area, namely, the Limpopo province, and perhaps even as far South as the Gauteng area. However, places like Kimberley and Gaborone find themselves in different climatic regions entirely, and so if they require their Bishop's prayers for rain, there seems no other option for him but to come to them. Thus, we can see that ritual, charismatic (suprahuman) leadership and land are all connected in this socio-religious complex.

In the past, the connections between sacred places and rain rituals were perhaps even more important. See for instance, the archeological article by Sven Ouzman on rituals conducted at Thaba Sione in North West province. (Despite the similarity in name and

4 One could even say his "divinity" is dependent on his status as a rainmaker, as revealed by Solomon's apparent change of mind [see above]. This connection might also have existed historically regarding the status of the chief, at least among the Tswana. Schapera states: "Our sources all agree that in the old days the Tswana expected their chiefs to provide them with rain, and that a chief's hold over his people might be affected by the nature of the rainfall during his rule" (Schapera 1971:133). 
the fact that ZCC members are actually also involved in the rituals performed here, this location appears to be unconnected to Moria.) Ouzman relates this to "Topophilia", "the feeling of attachment to certain geographical locations” (Ouzman 1994:4). Traditionally such places were often connected to either mountains or streams. However, in contemporary ZCC pilgrimage the "venue" is more often than not a sports stadium in the middle of a modern city. We know that such places often acquire their own sacral quality, a point quite possibly not lost on the ZCC either, yet the convenience of being able to accommodate thousands of people certainly plays a major role.

That the ZCC Bishop would accept these invitations to pray for rain, and thereby become the possible subject of pre-Christian religious connotations, even though he himself makes no claims to being a rainmaker, is clarified when looked at historically. One should consider it in the light of the long history of missionaries and Christian leaders, both black and white, who had over the centuries prayed for rain and inadvertently stepped into the role of the traditional rainmaker. Adrian Hastings describes how some missionaries, like Moffat and Livingstone, had attempted to argue the rationality of rainmaking with their converts, and in the case of Moffat outright rejected it. Most missionaries, however, followed a different tack. Starting from Van der Kemp, who in the early 1800s had successfully prayed for rain in the kraal of the Xhosa chief Ngqika, many missionaries found that they had to put the needs of their congregation above the demands of the rationality of their own modernism, and so they relented and prayed for rain when they were asked to do so. "Pressed by popular demand they responded like Van der Kemp as best they could. Again and again it worked" (Hastings 1994:315) ${ }^{5}$. Hastings suggests that great twentieth-century rainmakers, of whom he mentions Mutendi and Shembe - and I would add Lekganyane - were in this respect building on the heritage of their nineteenth century missionary predecessors (Hastings 1994:317). Whether this is really the case, or whether they

$5 \quad$ Cf also Chidester (1992:40) who states: "In this way, a Christian mission inserted itself into the local religious arena as an alternative 'environmental religion', making contested claims on the rain as a symbol of religious truth, meaning, and power. Throughout southern Africa, Christian missionaries entered into similar environmental, religious contests over rain”. 
were simply responding to the most acute ongoing need in this part of the African continent as all religious leaders, both Christian and Traditional, have done before them is an open question.

However, what the above perhaps illustrates is why water, and especially rain, acquired the sacral quality it did in Southern Africa. It is a direct result of its scarcity and the capricious nature with which it seems to be dispensed from above. It is perhaps an ironic side effect that the missionaries' ultimate understanding of, and willingness to appropriate "the African religious symbol of rain as a sign of their own exclusive, privileged religious authority and power" (Chidester 1992:40) might have in part led to the large scale twentieth-century defection to African Independent Churches. Yet, when one considers the African Traditional connections between the ancestors, divinity, and the one who prays for rain, we can see that it would have been logically impossible for the missionaries to fit entirely into this pattern. No matter how successful their prayers might have been, they were foreign spirits, unconnected to the ancestors. Thus their appropriation of African symbolism was ultimately doomed to failure and, in turn, African agency would come to the fore from the background.

\section{ENDURING POWER OF THE RAIN METAPHOR}

Within the context of the dry southern African climate, the name of the monetary currency of Botswana, the Pula (lit. rain), is exceedingly apt, as both traditionally as well as in the post-colonial agrarian economy, rain is not only a symbol but actually the only commodity that ensures survival for the majority and wealth for a few. Rain and the lack thereof, is the difference between well-being and destitution.

Small wonder then that rain, the focus of much, perhaps even most, pre-Christian religious activity should continue to occupy so large a niche within the current ZCC world. Regardless of the fact that most ZCC members, including the majority of my personal companions, are urbanites, some steps removed from the agricultural subsistence life-style of their ancestors, rain continues to inspire their imagination with all that is good and well, a cosmos in equilibrium.

Despite the tensions and contradictions experienced by members struggling to balance the competing realities of a sometimes revered, sometimes despised rural past and a frightening, 
yet exciting urban dream within their consciousness, the symbolic power of rain endures. And so as they travel between the worlds, both imaginatively and physically, through the act of pilgrimage, they keep the rain symbolism central. In the case of the physical pilgrimage, it is more specifically "the man with the key to rain" that forms the centre. In this too, the rationality of the ancestors remains prevalent.

Barnabas Lekganyane is of course no ordinary rainmaker. He talks less of rain and more of social concerns such as HIV and corruption. Evidently, he sees himself first and foremost as the Christian leader of a Christian church. Yet, he and his church exemplify an African Christianity that taps simultaneously into the more universal tenets of Christianity as interpreted from Scripture, and the deep wells (didiba) of African traditional culture and religion. In the eyes of many of his followers, Lekganyane might simultaneously be the Bishop of their church, as well as the paramount chief of their ZCC nation.

These outward-bound pilgrimages, where thousands of ZCC members follow Barnabas Lekganyane across southern Africa, might perhaps be interpreted as a symbolic reclamation and anointment of the physical landscape into the symbolic landscape of a reintegrated cultural-religious complex as represented by the ZCC's hybridised religious culture.

Moreover, by going on outward-bound pilgrimage in the wake of Bishop Lekganyane, ZCC members demonstrate that their reconceptualised world is more than a localised anomaly focusing on the "holy city" of Moria. They illustrate that their vision of a reintegrated world finds resonance across Southern Africa. This occurs to such an extent, in fact, that the international borders of the modern nation state - a fragmenting agency in itself - are transcended.

Through the reintegration of various cultural fragments the ZCC presents a culture that is not simply the sum of the total. Rather, a new unity is achieved with its own internal dynamic, which simultaneously seeks continuity with the past as well as posing interesting visions of an African Christian society in formation. At the head of their church stands a leader who is unmistakably Christian in addition to being the most visible symbol of a reconceptualised African Traditional culture. 


\section{CONCLUSION}

In summary: it appears that in a contemporary ZCC ritual of crossborder pilgrimage with the purpose of praying for rain, we may very well have a concrete example of the ongoing formation of a hybrid (border-crossing) religious culture in Southern Africa, which draws simultaneously on their Christian faith in the power of God to provide rain, and an older Sotho-Tswana cultural and religious heritage, which understands the power of God to be manifest in the traditional ruler's ability to command the rains. The hybridity of the culture is aptly illustrated by the fact that the traditional ruler's role becomes fulfilled by a contemporary church leader.

\section{Consulted literature}

Chidester, D 1992. Religions of South Africa. London: Routledge.

Comaroff, J \& Comaroff, J 1992. Ethnography and the Historical Imagination. Boulder: Westview Press.

Hanekom, C 1975. Geloofsopvattinge en seremonies binne 'n swart kerk. Kaapstad: Academia.

Hastings, A 1994. The Church in Africa 1450-1950. Oxford: Oxford University Press.

Krige, E J \& Krige, J D 1943. The Realm of a Rain-Queen: A Study of the Pattern of Lovedu Society. London: Oxford University Press.

Mucherera, T N 2001. Pastoral Care from a Third World Perspective: A Pastoral Theology of Care for the Urban Contemporary Shona in Zimbabwe. New York: P Lang.

Nchabeleng, S P 1983. “The Zion Christian Church of Ignatius Lekganyane: Its Origin, History and Character in Comparison with Reformed and with Traditional Structures”. B D thesis, University of the North.

Ouzman, S 1994. "Rain from the mountain of Zion”. The Digging Stick 11.4, 24.

Parrinder, G 1976. African Traditional Religion. New York: Harper \& Row.

Ramadubu, D 2005. ZCC Pilgrims descend on Gaborone in Botswana Guardian, Gaborone, 18-24 November.

Schapera, I 1971. Rainmaking Rites of Tswana Tribes. Leiden: AfrikaStudiecentrum.

Senthebeng, W K \& Majuta, A 2005. Exploding Myths about ZCC in Botswana Guardian. Gaborone, 2-8 December.

Van Wyk, J H 1986. Die Separatisme en Religieuse Bewegings onder die Sotho van die RSA. D.Phil (Anthropology) thesis, University of Pretoria.

Walls, A F 2002. The Cross-Cultural Process in Christian History. Maryknoll: Orbis Books. 
-, 1996. The Missionary Movement in Christian History: Studies in the Transmission of Faith. Maryknoll: Orbis Books.

Young, R F 2006. "God of a Thousand Heads": The Syncretism of Mission and the Mission of Syncretism, with Special Reference to The Catholic 'PseudoVedas' of $18^{\text {th }}$-Century South India. Paper presented at the $19^{\text {th }}$ European Conference on Modern South Asian Studies - ECMSAS, Leiden, The Netherlands, 27-30 June. 